\section{Leaf Attributes as Indices of Fruit Quality in Prune Tree Canopies}

\author{
S.M. Southwick, S.A. Weinbaum, T.T. Muraoka, W.R. Krueger, \\ K.A. Shackel, and J.T. Yeager \\ Pomology Department, University of California, Davis, CA 95616
}

Additional index words. Prunus domestics, canopy-light relationships, high-density orchards

\begin{abstract}
Leaf dry weight per leaf area (LDW/LA); weight of leaf $\mathbf{N}$ per unit leaf area (LN/LA); leaf dry weight (LDW); and fruit quality, particularly sugar per fruit (SF); fruit fresh weight (FFW); and fruit dry weight (FDW) were measured over a range of daily average incident photosynthetic photon flux values (PPF) (50 to $\left.1000 \mu \mathrm{mol} \cdot \mathrm{s}^{-1} \cdot \mathrm{m}^{-2}\right)$ in 7-year-old prune (Prunus domestics L. syn. 'Petite d'Agen') tree canopies. Linear or curvilinear relationships between these leaf attributes and fruit characteristics were significant over the PPF range. Analysis of LDW/LA or LN/LA may be used to indicate tree canopy locations in which fruit size and quality is limited by suboptimal PPF.
\end{abstract}

Various aspects of fruit quality, including size, color, shape, firmness, soluble solids concentration (SSC), and fresh weight have been positively associated with photosynthetic photon flux (PPF) within canopies of deciduous tree species (Barritt et al., 1987; Haynes and Gob, 1980; Jackson and Palmer, 1977a, 1977b; Robinson et al., 1983; Jackson et al., 1971, 1977; Roper and Loescher, 1987; Roper et al., 1987; Seeley et al., 1980). It has been suggested that the larger fruit in the outer portions of tree canopies result from better light exposure and proximity to leaves with higher photosynthetic capacity (Barritt et al., 1987; Ferree and Palmer, 1982; Freeman et al., 1981; Heinecke, 1966; Jackson et al., 1971; Seeley et al., 1980). Fruit are strong sinks for photoassimilates (Jackson, 1984; Nitsch, 1952), and leaves preferentially supply adjacent developing fruit with photoassimilates (Aldrich, 1936; Dann et al., 1984; Ferree and Palmer, 1982; Hansen, 1967, 1969; Hansen et al., 1982; Rom and Ferree, 1986; Roper et al., 1987).

The photosynthetic capacity of Prunus spp. leaves are positively related with PPF up to $\approx 700 \mu \mathrm{mol} \cdot \mathrm{s}^{-} \cdot \mathrm{m}^{-2}$ (DeJong, 1983 ; DeJong and Doyle, 1985). LDW/LA and LN/LA are also positively correlated with PPF (Aldrich, 1936; Barritt et al., 1987; DeJong, 1982, 1983; DeJong and Doyle,

Received for publication 3 Apr. 1989. We acknowledge the California Prune Board for partial funding of this work. We also thank Eric Nielsen for allowing us to conduct this study in his orchard. The cost of publishing this paper was defrayed in part by the payment of page charges. Under postal regulations, this paper therefore must be hereby marked advertisement solely to indicate this fact.

Abbreviations: FDW, fruit dry weight, FFW, fruit fresh weight; FHR, fruit hydration ratio; LDW, leaf dry weight; LDW/LA, leaf dry weight per leaf area; LN/LA, weight of leaf $\mathrm{N}$ per unit leaf area; $\mathrm{SF}$, sugar per fruit.
1985; Jackson et al., 1977; Marini and Marini, 1983; Weinbaum et al., 1989). LN/LA has been correlated positively with leaf photosynthetic. capacity (Aldrich, 1936; DeJong, 1982, 1983; DeJong and Doyle, 1985). LDW/LA and LN/LA appear indicative of both a) the light microenvironment within the canopy (DeJong and Doyle, 1985; Weinbaurn et al., 1989) and b) the photosynthetic capacity of those leaves. Our objective, therefore, was to assess the possibility of using leaf attributes (LDW, LDW/LA, and LN/LA) as physiological indicators of SF, FFW, and FDW. If successful, the use of foliar analysis could be extended to assess and modify canopy light microenvironment for the improvement of fruit quality.

This study was conducted during 1987 in a high-density commercial planting of 7-yearold 'French' prune trees budded on myro-
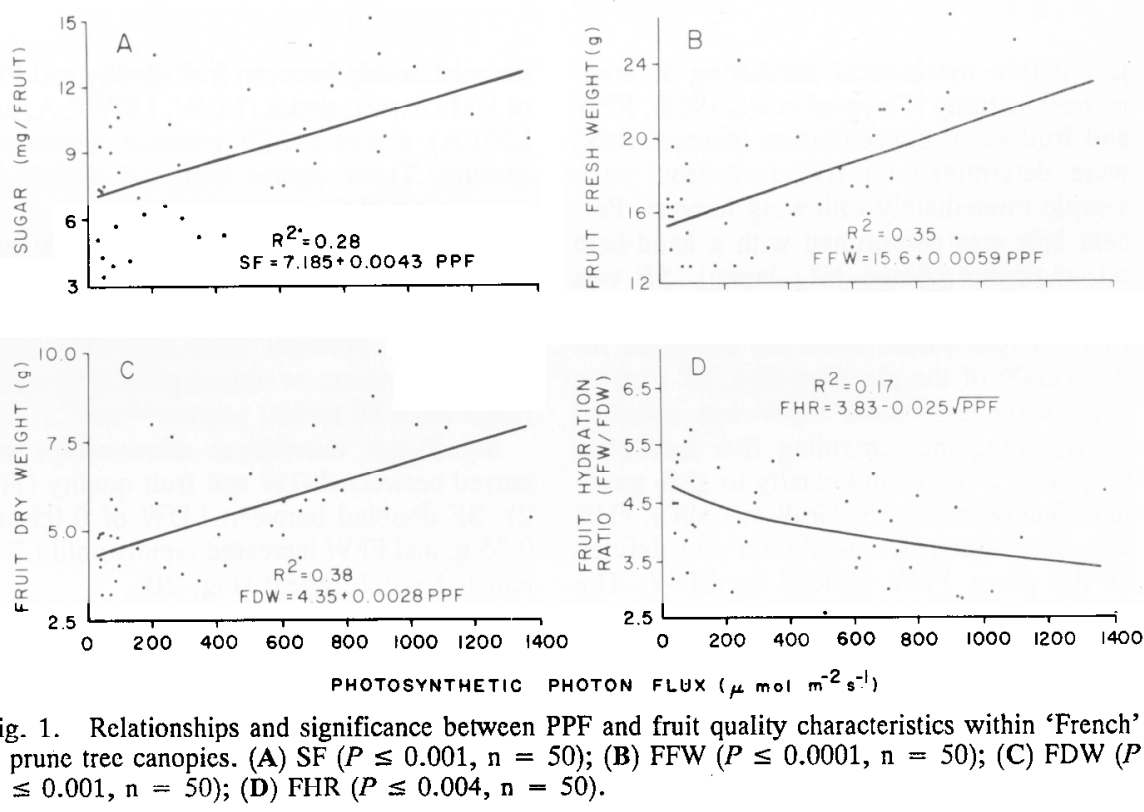

Fig. 1. Relationships and significance between PPF and fruit quality characteristics within 'French' prune tree canopies. (A) SF $(P \leq 0.001, \mathrm{n}=50)$; (B) FFW $(P \leq 0.0001, \mathrm{n}=50)$; (C) FDW $(P$ $\leq 0.001, \mathrm{n}=50)$; (D) FHR $(P \leq 0.004, \mathrm{n}=50)$.

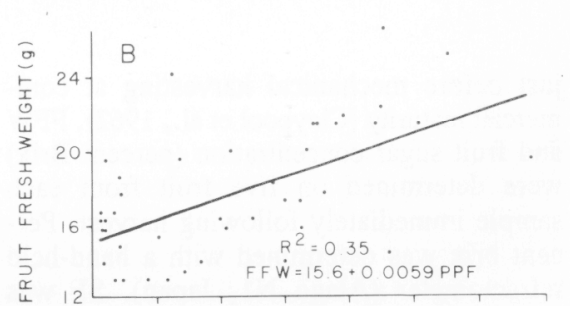

balan seedling rootstock. Trees were planted $2.7 \mathrm{~m}$ apart within the row and $4.9 \mathrm{~m}$ between rows (Weinbaum et al., 1989). Ten whole-tree replicates were selected at random from two rows of the orchard.

PPF was measured on prune tree canopies using five light sensors, as described by DeJong and Doyle (1985). Each sensor was individually calibrated with an LI-1905 quantum sensor (LI-COR, Lincoln, Neb.). The five sensors were monitored with a portable, battery-operated, microdata logger (CR21 Micrologger, Campbell Scientific, Logan, Utah). The logger scanned each sensor every $5 \mathrm{sec}$ and logged the data as an average over 6-hr intervals. Readings from 0600 to $1200 \mathrm{HR}$ and 1200 to $1800 \mathrm{HR}$ contained the most relevant PPF dues and were nearly identical (Weinbaum et al., 1989); therefore, data obtained at sensor positions between 0600 to 1200 HR were used in these analyses. Each sensor was secured to a vertical pole at fixed positions of 129, 190, 251, 312 , and $434 \mathrm{~cm}$ above the ground. The latter sensor was in full sun and represented the most exposed leaves. The pole with sensors was secured on the south side of each tree 1 $\mathrm{m}$ from the trunk. PPF was measured continuously over 3 to 4 cloudless days before moving to the next tree replicate. PPF was measured between July and early August.

Leaves were sampled at the time of average fruit maturity from the microenvironment of the light sensors, as described by Weinbaum et al. (1989). Twenty leaves within $20 \mathrm{~cm}$ of each sensor position were sampled from each sensor position. Determination of LDW, LDW/LA, and LN/LA, as well as measurements of leaf area, have been described (Weinbaum et al., 1989).

Ten fruit were sampled within a 30-to 40$\mathrm{cm}^{2}$ plane surrounding each sensor position 

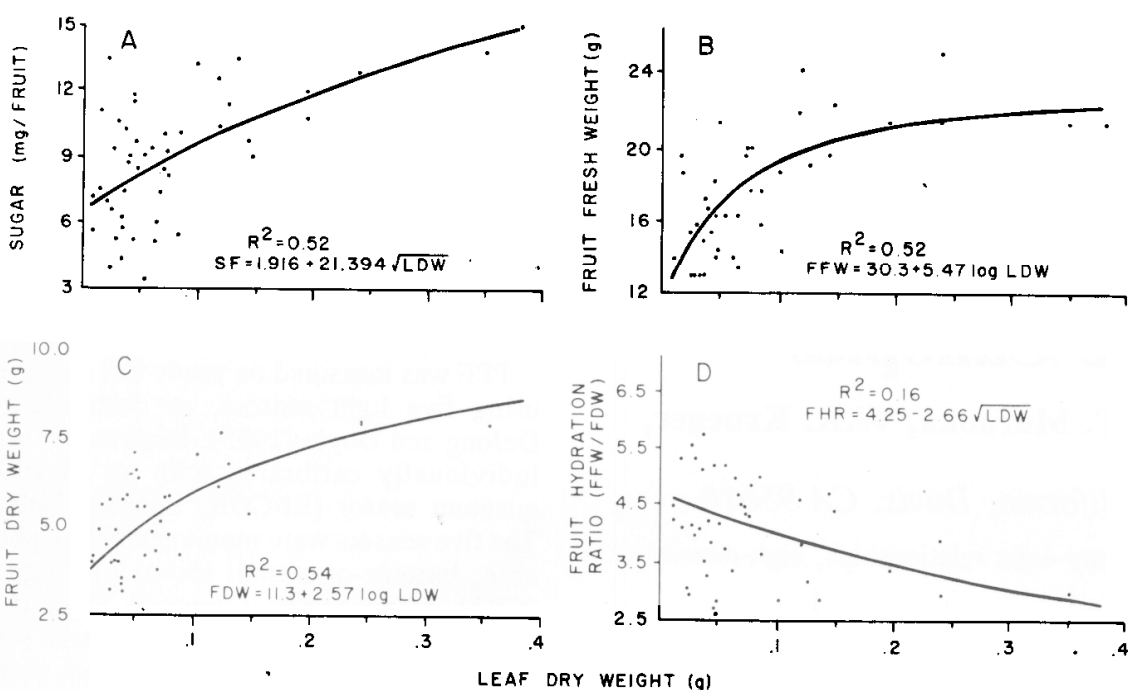

Fig. 2. Relationships and significance between LDW and fruit quality characteristics within 'French' prune tree canopies. (A) SF $(\mathrm{P} \leq 0.001, \mathrm{n}=50)$; (B) FFW $(\mathrm{P} \leq 0.0001, \mathrm{n}=50)$; (C) FDW (P $\leq 0.001, \mathrm{n}=50)$; (D) FHR $(P \leq 0.004, \mathrm{n}=50)$.
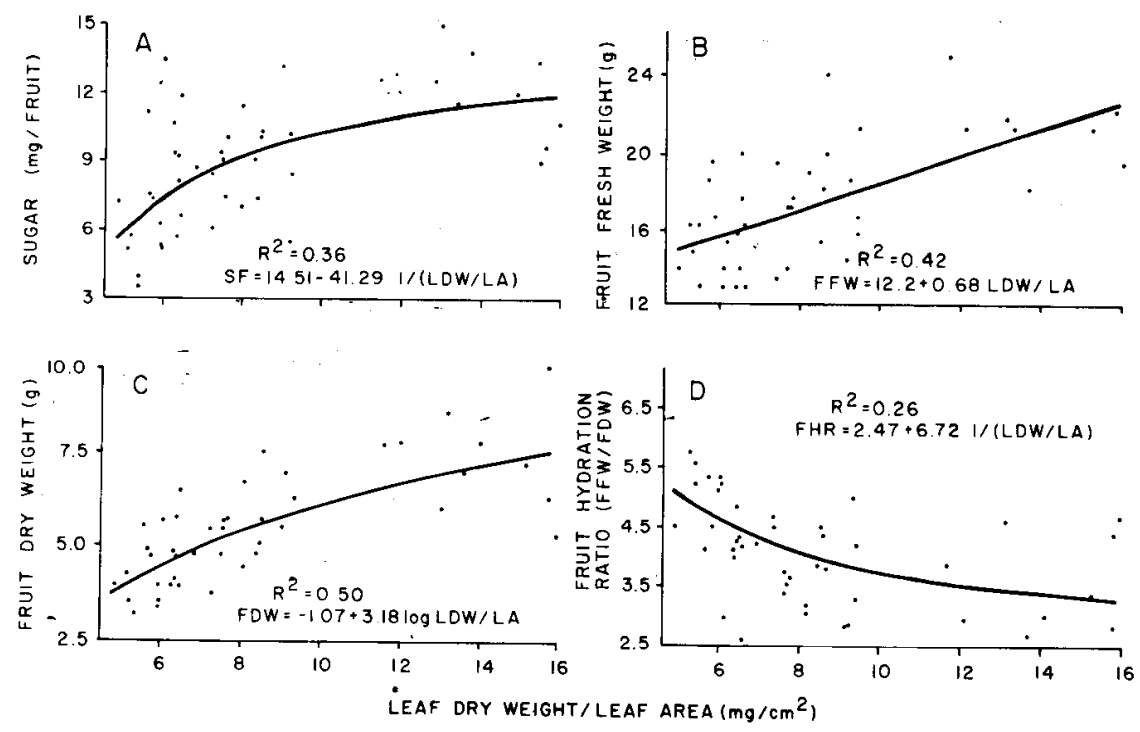

Fig. 3. Relationships and significance between LDW/LA and fruit quality characteristics within 'French' prune canopies. (A) SF $(P \leq 0.0001, \mathrm{n}=50)$; (B) FFW $(P \leq 0.0001, \mathrm{n}=50)$; (C) FDW $(P \leq$ $0.0001, \mathrm{n}=-50)$; (D) FHR $(P \leq 0.0001, \mathrm{n}=50)$

just before mechanical harvesting at commercial maturity (Claypool et al., 1962). FFW and fruit sugar concentration (percent Brix) were determined on five fruit from each sample immediately following harvest. Percent brix was determined with a hand-held refractometer (Atago N1, Japan). SF was calculated as the product of percent Brix and FFW. These values were not corrected for the weight of the pit; therefore, SF may be slightly overestimated. FDW was obtained by weighing the remaining five fruit after they were dried commercially to $18 \%$ moisture (SunSweet Dryers, Gridley, Calif.). FHR was determined by calculation and defined as the prune FFW divided by FDW. The higher the FHR values, the greater the expense in drying prunes to achieve the Commercial standard of $18 \%$ moisture content.

Curves of best fit through the data points were developed by using the Minitab (State College, $\mathrm{Pa}$.) computing package to describe the relationship between fruit quality and PPF or leaf characteristics (LDW, LDW/LA, and LN/LA) across a PPF gradient within the canopy. Those curves with the highest $\mathrm{R}^{2}$ were selected for presentation.

SF, FFW, and FDW were positively correlated with PPF (Fig. 1). A negative curvilinear expression best described the relationship between FHR and PPF. FHR appeared to decrease most rapidly over a PPF range from 50 to $300 \mu \mathrm{mol} \cdot \mathrm{s}^{-1} \cdot \mathrm{m}^{-2}$.

Significant curvilinear relationships occurred between LDW and fruit quality (Fig. 2). SF doubled between LDW of 0.05 and $0.35 \mathrm{~g}$, and FFW increased rapidly until LDW equaled $\approx 0.20 \mathrm{~g} /$ leaf (Fig. $2 \mathrm{~B}$ ).

FFW had an asymptotic maximum at $\approx 0.20 \mathrm{~g} \mathrm{LDW}$ (Fig. 2B). FHR, however, had a negative curvilinear relationship to LDW (Fig. 2D) and the relationship was less significant than that of other characteristics measured.
SF, FFW, and FDW increased significantly with increasing LDW/LA (Fig. 3). The greatest relative increase in SF and FDW occurred with changes in LDW/LA between 6 and 8. FHR exhibited a negative curvilinear relationship with LDW/LA and again was the least significant among quality attributes tested.

SF, FFW, and FDW increased significantly with LN/LA (Fig. 4). Linear relationships were evident when SF and FFW were plotted against LNLA. A curvilinear function best described the decrease in FHR as LN/LA increased.

LN/LA accounted for the greatest variability in fruit quality characteristics (Fig. 4), compared to either LDW or LDW/LA. Curves of fruit quality vs. LN/LA were similar to those relating fruit quality to PPF (Figs. 1 and 4). No leaf characteristic-accounted for $>26 \%$ of the variability in FHR and those best-fit equations were curvilinear (Figs. 1D 2D, 3D, 4D).

Our data confirm previous studies (Barritt et al., 1987; Jackson et al., 1971; Robinson et al., 1983) and show that fruit quality varies with the light microenvironment at various canopy coordinates. Changes in FFW and FDW were consistently associated with changes in PPF and leaf characteristics LDW, LDW/LA, and LN/LA, but the correlation did not account for a large percentage of the variability in fruit quality.

Several factors may have reduced the significance of these correlations. Since fruit and leaves originated as much as $20 \mathrm{~cm}$ from the light sensors, the measured PPF values may have varied considerably from those experienced by the tissues samples.

Although there is a strong tendency for the leaves nearest developing fruit to supply fruit with photoassimilate, fruit may be supplied by leaves in a different light microenvironment, i.e., $1 \mathrm{~m}$ or more from these fruit (Stephenson, 1981). In addition, fruit quality may be influenced by the intensity and quality of light impinging directly on the fruit (Erez and Flore, 1986).

Other factors, such as crop load or leaf area : fruit ratio, which influence the availability of photoassimilate, may affect fruit size, fruit quality, and the rate of fruit maturation (Overholser et al., 1944; Proebsting and Mills, 1981; Roper and Loescher, 1987; Roper et al., 1987; Stephenson, 1981; Weinberger, 1931). Lakso et al. (1989) have reported a significant interaction between crop load and canopy position on fruit size of 'Empire' apple and 'Concord' grape. Juice soluble solids were reduced more severely by shade if vines were heavily cropped (Lakso et al., 1989). Crop load influences the rate at which fruit accumulate soluble solids (Proebsting and Mills, 1981). The poor correlation we found between PPF and percent Brix may reflect a confounding effect of different branch leaf area : fruit ratios at the various light sensor locations (data not shown). Fruit size has also been inversely related to crop load (Proebsting and Mills, 1981). The effect of crop load on leaf characteristics (LDW, LN/LA, and LDW/LA), 

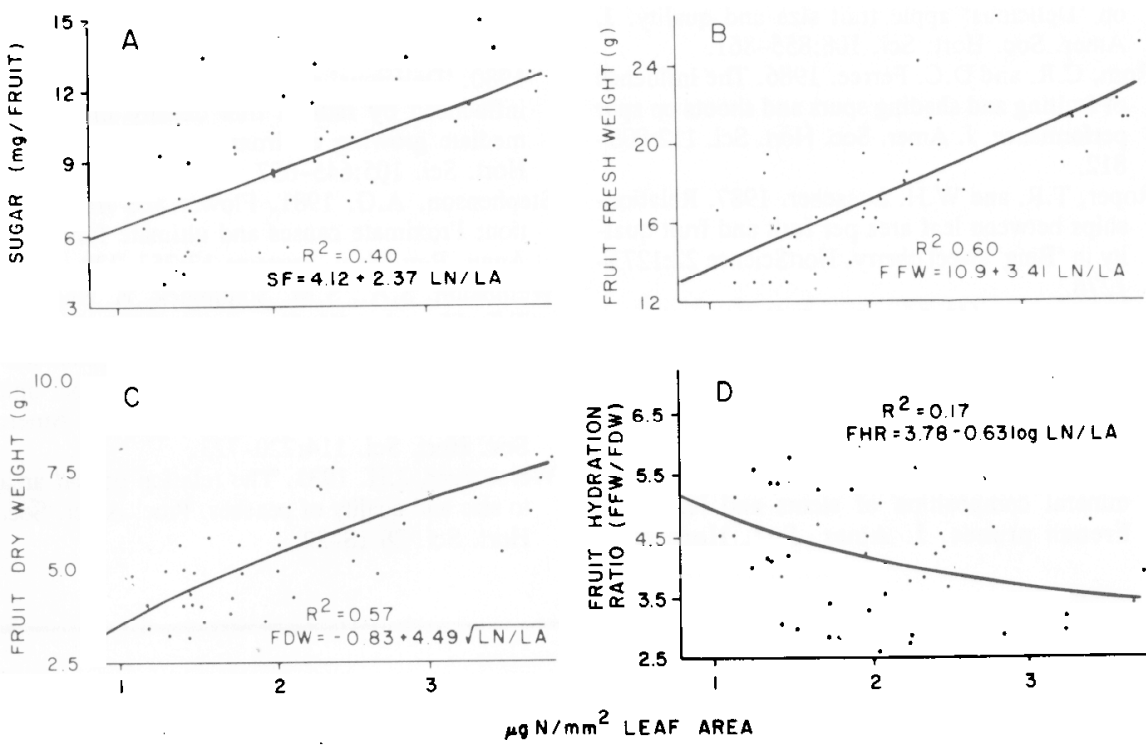

Fig. 4. Relationships and significance between LN/LA and fruit quality characteristics within 'French'

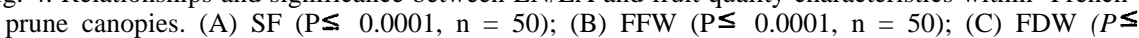
$0.0001, \mathrm{n}=50)$; (D) FHR $(\mathrm{P} \leq 0.0001, \mathrm{n}=50)$.

however, has not yet been determined.

Favorable orchard returns are generated by moderate crops of 6 to 7 dry tha ${ }^{-1}$ of 130 to 150 dried prunes $/ \mathrm{kg}$ ( 7.45 to $6.50 \mathrm{~g} /$ prune). A small prune is in the range of $<5.0 \mathrm{~g}$ (dry weight). Prune growers are paid relative to the number of dried prunes per kilogram. An average $\mathrm{PPF}$ of $235 \mu \mathrm{mol} \cdot \mathrm{s}^{-1} \cdot \mathrm{m}^{-2}$ within the canopy was required for developing fruit to produce prunes that weigh $5 \mathrm{~g}$. For every $100 \mu \mathrm{mol} \cdot \mathrm{s}^{-1} \cdot \mathrm{m}^{-2}$ increase in PPF, FDW increased by $0.28 \mathrm{~g}$. Similar values for LDW, LDW/LA, and LN/LA that were critical for fruit size over $5.0 \mathrm{~g}$ were $\approx 0.06,7.2$, and 1.8 , respectively. Similar analyses could be made for SF, FFW, and FHR; however, the FDW and FHR are the economic measures of most interest.

Profit can be increased by producing prunes that have lower FHRs. In such fruit, every gram of prune fresh weight yields a greater percentage of dry weight, which results in less time required for dehydration. Lower FHRs are found in prune fruit with higher SSC (Claypool et al., 1962). Fruit with lower SSC and higher FHR have been harvested from the interior of prune tree canopies (Freeman et al., 1981). Leaf area per fruit has been positively correlated with fruit SSC (Roper and Loescher, 1987) and has also contributed most to fruit weight and SSC variability in 'Bing' sweet cherry. In the work presented here, significant, nonlinear negative relationships were found between FHR and, PPF, LDW, LDW/LA, and LN/LA. These relationships were not as well correlated as those measured for other fruit quality characteristics, indicating that other factors not associated with low light contributed to higher drying ratios. Variability in limb crop load could be one factor contributing to the variability in FHR within canopy locations exposed to varying PPF. The equations presented here cannot be used to determine the quantitative effect of PPF on FHR until equations can be modified to account for the effects of crop load.

LDW/LA and LN/LA vary positively with incident PPF (DeJong and Doyle, 1985; Marini and Marini, 1983; Ryugo et al., 1977; Weinbaum et al., 1989). The most significant correlations were demonstrated between LDW/LA and LN/LA and fruit quality (specifically SF, FFW, and FDW). Since these two leaf characteristics integrate the light microenvironment at the canopy coordinates sampled (Weinbaum et al., 1989) and LDW/LAs are influenced by the presence of fruit on those limbs on which they are borne (Hansen et al., 1982), these leaf characteristics might be used as indicators of fruit quality. These best-fit equations, which incorporate leaf characters, could be used to identify shaded regions within the canopy, i.e., where PPF limits fruit size.

Since the current experiments were conducted in one orchard location in 1 year, we do not know how the-equations of best fit between leaf and fruit quality would be affected by varying crop load, cultivar, or other environmental factors. However, Hansen et al. (1982) have shown that LDW/LA on bearing limbs are lower than those on nonbearing limbs. Possible effects of varying crop loads on the relationship between PPF leaf characteristics and fruit quality must, therefore, be determined. These leaf characteristics, in conjunction with reference date fruit size, may be useful in determining when tree management (e.g., pruning) practices should be altered to increase the PPF within prune tree canopies.

\section{Literature Cited}

Aldrich, W.W. 1936. Relative efficiency of spur and shoot leaves for fruit growth of pears. Proc. Amer. Soc. Hort. Sci. 34:227-232.

Barritt, B. H., C.R. Rem, K.R. Guelich, S.R. Drake, and M.A. Dilley. 1987. Canopy position and light effects on spur, leaf, and fruit characteristics of 'Delicious' apple. HortScience 22:402-405.

Claypool, L. L., W.H. Dempsey, P. Esau, and

M.W. Miller. 1962. Physical and chemical changes in French prunes during maturation in coastal valleys. Hilgardia 33:311-348.

Dann, I. R., R.A. Wildes, and J.J. Chalmers. 1984. Effects of limb girdling on growth and development of. competing fruit and vegetative tissues of peach trees. Austral J. Plant Physiol. 11:49-58.

DeJong, T.M. 1982. Leaf nitrogen content and $\mathrm{CO}$, assimilation capacity in peach. J. Amer. Soc. Hort. Sci. 107:955-959.

DeJong, T.M. 1983. CO assimilation characteristics of five Prunus tree fruit species. J. Amer. Soc. Hort. Sci. 108:303-307.

DeJong, T.M. and J.F. Doyle. 1985. Seasonal relationships between leaf nitrogen content (photosynthetic capacity) and leaf canopy light exposure in peach (Prunus persica). Plant, Cell \& Environ. 8:701-706.

Erez. A. and J.A. Flore. 1986. The quantitative effect of solar radiation on 'Redhaven' peach fruit skin color. HortScience 21:1424-1426.

Ferree, D.C. and J.W. Palmer. 1982. Effect of spur defoliation and ringing during bloom on fruiting, fruit mineral level, and photosynthesis of 'Golden Delicious' apple. J. Amer. Soc. Hort. Sci. 107:1182-1185.

Freeman, M., L. Fitch, J. Connell, and W. Olson. 1981. Quality differences between inside and outside fruit. Sun-Diamond Grower. Aug./Sept. p. 11.

Hansen, P. 1967. ${ }^{14} \mathrm{C}$-Studies on apple trees. I. The effect of the fruit on the translocation and distribution of photosynthates. Physiol. Plant. 20:382-391.

Hansen, P. 1969. ${ }^{14} \mathrm{C}$-Studies on apple trees. IV. Photosynthate consumption in fruits in relation to the leaf-fruit ratio and to the leaf-fruit position. Physiol. Plant. 22: 186-198.

Hansen, P., K. Ryugo, D.E. Ramos, and L. Fitch. 1982. Influence of cropping on $\mathrm{Ca}, \mathrm{K}, \mathrm{Mg}$, and carbohydrate status of 'French' prune trees grown on potassium limited soils. J. Amer. Soc. Hort. Sci. 107:511-515.

Haynes. R.J. and K.M. Gob. 1980. Variation in the nutrient content of leaves and fruit with season and crown position for two apple varieties. Austral. J. Agr. Res. 31:739-747.

Heinecke, D.R. 1966. Characteristics of McIntosh and Red Delicious apple as influenced by exposure to sunlight during the growing season. Proc. Amer. Soc. Hort. Sci. 89:10-13.

Jackson, J.E. 1984. Effects of cropping on tree vigor. Acta Hort. 146:83-88.

Jackson, J.E. and J.W. Palmer. 1977a. Effects of shade on the growth and cropping of apple trees. I. Experimental details and effects on vegetative growth. J. Hort. Sci. 52:245-252.

Jackson, J.E. and J.W. Palmer. 1977b. Effects of shade on the growth and cropping of apple trees. II. Effects on components of yield. J. Hort. Sci. 52:253-266.

Jackson, J. E., J.W. Palmer, M.A. Perring, and R.O. Sharples. 1977. Effects of shade on the growth and cropping of apple trees. III. Effects on fruit growth, chemical composition and quality at harvest and after storage. J. Hort. Sci. 52:267282.

Jackson, J. E., R.O. Sharples, and J.W. Palmer. 1971. The influence of shade and within-tree position on apple fruit size, color and storage quality. J. Hort. Sci. 46:277-287.

Lakso, A. N., T.L. Robinson, and R.M. Pool. 1989. Canopy microclimate effects on patterns of fruiting and fruit development in apples and grapes, p. 263-274. In: C.J. Wright (cd.). Manipulation of fruiting. Butterworths, London. 
Marini, R.P. and M.C. Marini. 1983. Seasonal changes in specific leaf weight, net photosynthesis, and chlorophyll content of peach leaves as affected by light penetration and canopy position. J. Amer. Soc. Hort. Sci. 108:600-605.

Nitsch, J.P. 1952. Plant hormones in the development of fruits. Quart. Biol. Rev. 27:33-57.

Overholser, E. L., C.L. Bedford, and A. L., Ken-, worthy. 1944. The relationship of leaf area per plum to physical properties and chemical composition. Proc. Amer. Soc. Hort. Sci. 44:9498.

Procbsting, E.L. and H.H. Mills. 1981. Effects of season and crop load on maturity characteristics of' 'Bing' cherry. J. Amer. Soc. Hort. Sci. 106:144-146.

Robinson, T. L., E.J. Seeley, and B. H. Barritt 1983. Effect of light environment and spur age on 'Delicious' apple fruit size and quality. J. Amer. Soc. Hort. Sci. 108:855-861.

Rem, C.R. and D.C. Ferree. 1986. The influence of fruiting and shading spurs and shoots on spur performance. J. Amer. Soc. Hort. Sci. 112:808812.

Roper, T.R. and W.H. Loescher. 1987. Relationships between leaf area per fruit and fruit quality in 'Bing' sweet cherry. HortScience 22:12731276.

Roper, T. R., W.H. Loescher, J. Keller, and C.R. Rem. 1987. Sources of photosynthate for fruit growth in 'Bing' sweet cherry. J. Amer. Soc. Hort. Sci. 112:808-812.

Ryugo, K., N. Nii, M. Iwata, and R.M. Carlson. 1977. Effect of fruiting on carbohydrates and mineral composition of stems and leaves of French prunes. J. Amer. Soc. Hort. Sci.
102:813-816.

Seeley, E. J., W.C. Micke, and R. Kammereck. 1980. 'Delicious' apple fruit size and quality as influenced by radiant flux density in the immediate growing environment. J. Amer. Soc. Hort. Sci. 105:645-657.

Stephenson, A.G. 1981. Flower and fruit abortion: Proximate causes and ultimate functions. Annu. Rev. Ecol. Systems 12:253-279.

Weinbaum, S. A., S.M. Southwick, K. Shackel, T.T. Muraoka, W. Krueger, and J.T. Yeager. 1989. Photosynthetic photon flux influence macroelement weight and leaf dry weight per unit of leaf area in prune tree canopies. J. Amer. Soc. Hort. Sci. 114:720-723.

Weinberger, J.H. 1931. The relation of leaf area to size and quality of peaches. Proc. Amer. Soc. Hort. Sci. 28:18-22. 